\title{
MENUJU TIGA DEKADE PERKEMBANGAN PERBANKAN SYARIAH DI INDONESIA
}

\author{
Ari Sita Nastiti \\ Program Studi Akuntansi Universitas Muhammadiyah Jember \\ arisitanastiti@unmuhjember.ac.id \\ Agung Ivan Firdaus \\ Program Studi Akuntansi Universitas Muhammadiyah Jember \\ agungivan743@gmail.com
}

\begin{abstract}
Abstrak: Perbankan syariah di Indonesia telah berkembang hampir mencapai tiga dekade sejak beroperasinya Bank Muamalat Indonesia, sebagai bank syariah pertama di Indonesia. Perkembangan industri perbankan syariah telah membuahkan berbagai prestasi, dari makin banyaknya produk dan layanan, hingga berkembangnya infrastruktur yang mendukung keuangan syariah. Namun demikian, pertumbuhan perbankan syariah belum dapat mengimbangi pertumbuhan perbankan konvensional. Hal ini dapat dilihat dari pangsa pasar (market share) perbankan syariah yang secara keseluruhan masih mencapai rata-rata $5 \%$ dari seluruh aset perbankan nasional. Oleh karenanya penelitian ini bertujuan untuk mengkaji perkembangan industri perbankan syariah dalam tiga dasawarsa terakhir. Hasil penelitian ini diharapkan dapat memberikan wawasan mengenai perkembangan bank syariah di Indonesia serta mampu memunculkan gagasan untuk memajukan perekonomian syariah lebih baik ke depan guna terwujudnya Indonesia sebagai pusat keuangan syariah dunia.

Metode yang digunakan dalam penelitian ini adalah metode kualitatif dengan teknik studi literatur atau studi pustaka (Library Research). Hasil dari penelitian ini memperlihatkan bahwa selama tiga dekade terakhir, bank syariah di Indonesia mengalami berbagai kejadian-kejadian ekonomi yang mempengaruhi perkembangannya. Oleh karenanya, industri perbankan syariah dituntut untuk memiliki daya tahan agar mampu menghadapi perubahan dan ketidakpastian
\end{abstract}

Kata Kunci : Bank Umum Syariah, Dekade, Ekonomi Islam, Perbankan Syariah, Riba.

\section{PENDAHULUAN}

Bank Muamalat didirikan atas inisiasi masyarakat muslim di Indonesia yang menginginkan sistem perbankan tanpa bunga. Bank Muamalat resmi beroperasi terhitung sejak tanggal $1 \mathrm{Mei}$ 1992 (www.ojk.go.id).

Kemampuan Bank Muamalat bertahan pada saat krisis ekonomi di tahun 1998, menarik minat masyarakat dan para investor terhadap sistem perbankan syariah. Terlebih dengan diberlakukannya UU No. 10 tahun 1998 tentang perubahan UU No. 7 tahun 1992 tentang Perbankan, yang memberikan landasan hukum lebih kuat bagi pengembangan perbankan syariah 
di Indonesia. Hal tersebut menginisisasi munculnya bank syariah kedua di Indonesia, yatu Bank Syariah Mandiri, yang mulai resmi beroperasi pada tanggal 1 November 1999. Selanjutnya pun diterbitkan pula beberapa landasan hukum untuk mengakomodir perkembangan entitas syariah di Indonesia, diantaranya adalah UU

No.21 tahun 2008 tentang Perbankan Syariah (www.ojk.go.id).

Data Perkembangan aset, Pembiayaan yang Diberikan (PYD) dan Dana Pihak Ketiga (DPK) industri perbankan syariah dalam 4 tahun terakhir dapat dilihat dalam Tabel 1 di bawah ini:

Tabel 1

\section{Perkembangan Aset, PYD dan DPK Industri Perbankan Syariah}

Tahun 2015-2018

(Dalam Triliun Rupiah)

\begin{tabular}{|l|c|c|c|c|}
\hline \multicolumn{1}{|c|}{ Komponen } & $\mathbf{2 0 1 5}$ & $\mathbf{2 0 1 6}$ & $\mathbf{2 0 1 7}$ & $\mathbf{2 0 1 8}$ \\
\hline Total Aset & 304,00 & 365,6 & 424,1 & 477,3 \\
\hline $\begin{array}{l}\text { Pembiayaan yang } \\
\text { Diberikan (PYD) }\end{array}$ & 218,72 & 254,7 & 293,5 & 329,3 \\
\hline $\begin{array}{l}\text { Dana Pihak Ketiga } \\
\text { (DPK) }\end{array}$ & 236,02 & 285,2 & 341,9 & 379,9 \\
\hline
\end{tabular}

Sumber: Statistik Perbankan Syariah 2018

Perbankan syariah di Indonesia telah berkembang hampir mencapai tiga dekade sejak beroperasinya Bank Muamalat Indonesia, sebagai bank syariah pertama di Indonesia. Perkembangan industri perbankan syariah telah membuahkan berbagai prestasi, dari makin banyaknya produk dan layanan, hingga berkembangnya infrastruktur yang mendukung keuangan syariah. Namun demikian, pertumbuhan perbankan syariah belum dapat mengimbangi pertumbuhan perbankan konvensional. Hal ini dapat dilihat dari pangsa pasar (market share) perbankan syariah yang secara keseluruhan masih mencapai rata-rata 5\% dari seluruh aset perbankan nasional. Hasil tersebut menunjukkan bahwa perbankan syariah Indonesia masih perlu terus dikembangkan sehingga dapat mengimbangi pertumbuhan perbankan konvensional dalam rangka membesarkan industri keuangan secara keseluruhan. 
Hal ini cukup disayangkan, mengingat Negara Indonesia merupakan negara dengan jumlah penduduk muslim terbesar di dunia. Terlebih semenjak dikeluarkannya fatwa MUI yang menyatakan bahwa Bunga Bank (riba) sama dengan haram. Hal tersebut seharusnya menjadi potensi yang besar bagi perkembangan perekonomian islam.

Berdasarkan latar belakang tersebut di atas, penelitian ini bertujuan untuk mengkaji perkembangan industri perbankan syariah dalam tiga dasawarsa terakhir. Hasil penelitian ini diharapkan dapat memberikan wawasan terhadap para pembaca mengenai perkembangan bank syariah di Indonesia serta mampu memunculkan gagasan untuk memajukan perekonomian syariah lebih baik ke depan.

Penelitian ini menggunakan metode studi literatur dengan meneliti artikel-artikel ilmiah, penelitianpenelitian, laporan resmi maupun pustaka lainnya yang mendukung topik dari penelitian ini. Penelitian ini juga lebih memfokuskan pembahasannya pada Bank Umum Syariah (BUS).
2. TIGA

DEKADE

PERKEMBANGAN

BANK SYARIAH DI INDONESIA

\subsection{Dekade Pertama (Tahun 1992- 2001)}

Dekade awal perkembangan bank syariah di Indonesia ditandai dengan berdirinya PT Bank Muamalat Indonesia, Tbk (BMI) yang resmi beroperasi pada tanggal 1 Mei 1992 (OJK, 2019). Landasan hukum Bank Syariah pada dekade awal ini adalah Undang-Undang (UU) No. 7 Tahun 1992. Landasan hukum tersebut masih belum cukup mengakomodir operasional bank syariah, karena hanya mencakup 1 ayat mengenai "bank dengan sistem bagi hasil" tanpa adanya rincian yang lebih jelas (OJK, 2019). Terbatasnya landasan hukum serta minimnya informasi masyarakat mengenai bank syariah menyebabkan bank syariah kurang diminati oleh masyarakat sehingga perkembangannya berjalan lambat.

Pada awal Juli 1997 terjadi krisis moneter di Indonesia yang menyebabkan penurunan nilai tukar rupiah terhadap dollar Amerika. Krisis moneter ini terjadi dikarenakan adanya krisis kualitas lembaga-lembaga keuangan yang berbasis pada penerapan 
suku bunga. Tingginya nilai suku bunga sebagai penyebab dari krisis moneter mengakibatkan ambruknya dunia perbankan dan sektor riil yang berpengaruh pada ketidakstabilan pertumbuhan ekonomi.

Berbeda halnya dengan bank-bank konvensional, BMI sebagai satusatunya bank syariah di Indonesia mampu bertahan ditengah gempuran krisis, bahkan tanpa bantuan BLBI dari pemerintah. Meskipun pada saat krisis, tercatat rasio pembiayaan macet (NPF) BMI lebih dari $60 \%$ dan rugi sekitar 100 milyar (Amin, 2007). Amin (2007) selanjutnya menjelaskan bahwa dalam konteks BMI, nilai-nilai syariahlah yang menjadi pegangan bagi setiap orang yang bekerja dalam bank tersebut. Kemudian nilai-nilai syariah tersebut dikonkritkan dalam bentuk nyata sebagai budaya perilaku kerja pada seluruh elemen yang membawa perusahaan mampu mengatasi kemudian bangkit dari situasi-situasi sulit yang dihadapi.

Krisis ekonomi 1997-1998 dapat dikatakan sebagai momentum kebangkitan perbankan syariah di Indonesia. Masyarakat mulai tertarik untuk berinvestasi dan menggunakan jasa bank syariah. Terlebih sejak pemerintah dan Dewan Perwakilan Rakyat melakukan penyempurnaan UU No. 7 Tahun 1992 menjadi UU No. 10 Tahun 1998, yang secara tegas menjelaskan bahwa terdapat dua sistem dalam perbankan di tanah air (dual banking system). Setelah dikeluarkannya ketentuan perundangundangan tersebut, sistem perbankan syariah sejak tahun 1998 telah menunjukkan perkembangan yang cukup pesat, yaitu sekitar $74 \%$ pertumbuhan aset per tahun (BI, 2019). Di samping itu, sebagai respon atas diberlakukannya UU No. 10 tahun 1998, PT Bank Syariah Mandiri (BSM) secara resmi mulai beroperasi pada tanggal $1 \quad$ November 1999 (www.syariahmandiri.co.id).

Pada akhir dekade awal ini, dalam kurun waktu tahun 1998 - 2001, aset sistem perbankan syariah mengalami pertumbuhan yang cukup pesat yaitu sebesar $74 \%$ pertahun. Sistem perbankan syariah telah pula mengalami pertumbuhan dalam hal kelembagaan. Namun, meskipun pertumbuhan bank syariah relatif cepat, namun kontribusi sistem perbankan syariah terhadap sistem perbankan nasional masih kecil, yaitu hanya sekitar $0.26 \%$ dari total aset perbankan nasional (BI, 2019). 
2.2 Dekade Kedua (Tahun 2002-2011)

Pada dekade kedua ini, di tahun 2004, PT Bank Syariah Mega Indonesia (BSMI) resmi menjadi bank umum syariah ketiga di Indonesia, menyusul BMI dan BSM yang telah beroperasional sebelumnya

Dengan ketiga bank umum syariah yang beroperasi, industri perbankan syariah menunjukkan peningkatan dari segi total aset, penghimpunan dana maupun pembiayaan. Namun apabila ditinjau dari pangsa total aset perbankan syariah dibandingkan perbankan konvensional masih relatif kecil, yaitu baru mencapai $1,84 \%$ pada Desember 2007 (Permana dan Purba, 2008).

Untuk lebih mendorong peningkatan industri perbankan syariah nasional, maka dipandang perlu adanya Undang-Undang Perbankan Syariah yang terpisah dari Undang-undang Perbankan Konvensional. Untuk itu, disahkanlah UU nomor 21 Tahun 2008 tentang Perbankan Syariah.

Dengan adanya dukungan seperangkat aturan yang memadai di bidang perbankan syariah, serta semakin bertambahnya instrumen keuangan syariah diharapkan akan semakin menarik investor/pelaku bisnis pada khususnya dan masyarakat pada umumnya, untuk berinvestasi dan menggunakan jasa perbankan syariah (Permana dan Purba, 2008).

Pengesahan UU nomor 21 Tahun 2008 tentang Perbankan Syariah, terbukti mampu mendorong pertumbuhan industri perbankan syariah, salah satunya dalam hal peningkatan jumlah Bank Syariah di Indonesia. Pada tanggal 9 Desember 2008, PT Bank Syariah Bukopin menjadi bank keempat yang beroperasi dengan prinsip syariah di Indonesia (www.syariahbukopin.co.id).

Selanjutnya pada tahun 2009-2010, banyak bank yang secara resmi menyusul beroperasi dengan menggunakan prinsip syariah, yaitu: Panin Bank Syariah, BRI Syariah, Bank Victoria Syariah, BCA Syariah, Bank Jabar Banten Syariah, BNI Syariah, Maybank Syariah. Sampai dengan akhir dekade kedua, terdapat 11 Bank Umum Syariah yang beroperasi di Indonesia sebagaimana dapat dilihat pada Tabel 2 di bawah ini: 
Tabel. 2 Daftar Bank Umum Syariah yang Beroperasi

Pada Dekade Kedua

\begin{tabular}{|c|l|c|}
\hline NO & \multicolumn{1}{|c|}{ NAMA BANK } & $\begin{array}{c}\text { TANGGAL } \\
\text { OPERASIONAL }\end{array}$ \\
\hline 1 & Bank Muamalat Indonesia (BMI) & 1 Mei 1992 \\
\hline 2 & Bank Syariah Mandiri (BSM) & 1 November 1999 \\
\hline 3 & Bank Mega Syariah & 25 Agustus 2004 \\
\hline 4 & Bank Syariah Bukopin & 9 Desember 2008 \\
\hline 5 & Panin Bank Syariah & 6 Oktober 2009 \\
\hline 6 & Bank Rakyat Indonesia(BRI) Syariah & 15 Desember 2009 \\
\hline 7 & Bank Victoria Syariah & 1 April 2010 \\
\hline 8 & Bank Central Asia (BCA) Syariah & 5 April 2010 \\
\hline 9 & Bank Jabar Banten Syariah & 6 Mei 2010 \\
\hline 10 & Bank Negara Indonesia (BNI) Syariah & 19 Juni 2010 \\
\hline 11 & Maybank Syariah & 11 Oktober 2010 \\
\hline
\end{tabular}

Sumber: Data diolah, 2019

Pada tahun 2008, terjadi krisis di Amerika Serikat (AS) yang mempengaruhi keuangan global. Rekayasa instrumen keuangan yang berbentuk subprime mortgage di tahun 2001-2005 menjadi salah satu sebab timbulnya krisis ekonomi di AS (Sudarsono, 2009). Raz, et. al (2012) mengemukakan bahwa sejak era globalisasi, krisis keuangan menjadi lebih sering terjadi daripada sebelumnya. Salah satu alasan utamanya adalah kemajuan dalam teknologi informasi, yang sampai batas tertentu, memperbesar gelombang krisis dan mempercepat penyebarannya ke negara lain. Di samping itu, munculnya International Financial Integration (sistem keuangan yang terintegrasi) menyebabkan gangguan keuangan domestik di satu negara dapat mengakibatkan efek domino yang mengacaukan ekonomi terintegrasi lainnya sehingga mengarah pada kekacauan keuangan global.

Adapun dampak krisis tersebut bagi perekonomian Indonesia, khususnya industri perbankan, ditandai dengan adanya penarikan dana khususnya dolar AS oleh investor di luar negeri. Hal tersebut mengakibatkan bank mengalami krisis likuiditas dan penurunan nilai aktiva produktif (earning assets). Namun, pengalaman krisis keuangan tahun 1998-2003 telah membawa industri perbankan Indonesia mampu bertahan dalam krisis 2008. Hal ini dikarenakan krisis 1998 telah 
mempengaruhi perbaikan pada beberapa aspek, antara lain transparansi yang memenuhi akuntabilitas dan efektifitas, profesionalisme dan kompetensi, pemenuhan ketentuan perbankan dan prinsip kehati-hatian (Sudarsono, 2009)

Lebih lanjut, Sudarsono (2009) dalam penelitiannya mengenai dampak krisis global tahun 2008 terhadap perbankan nasional menyimpulkan bahwa sistem perbankan syariah lebih stabil dibandingkan dengan bank konvensional dalam menghadapi krisis keuangan global. Sistem keuangan syariah yang tidak mengenal bunga menjadikan bank syariah mampu bertahan dari fluktuasi tingkat bunga yang disebabkan oleh turunnya nilai rupiah yang disebabkan langkanya dolar di pasar. Selain itu, kinerja keuangan bank syariah dibandingkan dengan bank konvensional menunjukkan kondisi keuangan yang konsisten dan efisien.
Industri perbankan syariah mampu menunjukkan akselerasi pertumbuhan yang tinggi dengan rata-rata sebesar 40,2\% pertahun dalam lima tahun terakhir (2007-2011), sementara ratarata pertumbuhan perbankan nasional hanya sebesar $16,7 \%$ pertahun. Oleh karena itu, industri perbankan syariah dijuluki sebagai the fastest growing industry. Akselerasi pertumbuhan perbankan syariah yang jauh lebih tinggi dari pertumbuhan perbankan nasional berhasil meningkatkan porsi perbankan syariah dalam perbankan nasional menjadi 4,0\% (Alamsyah, 2012).

Berikut adalah data perkembangan kinerja keuangan industri perbankan syariah selama dekade kedua sebagaimana tercantum pada Tabel 3 di bawah ini:

Tabel 3 Perkembangan Aset, PYD dan DPK

Industri Perbankan Syariah pada Dekade Kedua (2002-2011)

(Dalam Miliar Rp)

\begin{tabular}{|l|l|c|c|c|c|c|c|c|c|c|c|}
\hline & \multirow{2}{*}{ Komponen } & \multicolumn{9}{|c|}{ Tahun } \\
\cline { 3 - 13 } & & $\mathbf{2 0 0 2}$ & $\mathbf{2 0 0 3}$ & $\mathbf{2 0 0 4}$ & $\mathbf{2 0 0 5}$ & $\mathbf{2 0 0 6}$ & $\mathbf{2 0 0 7}$ & $\mathbf{2 0 0 8}$ & $\mathbf{2 0 0 9}$ & $\mathbf{2 0 1 0}$ & $\mathbf{2 0 1 1}$ \\
\hline 1. & Total Aset & 4.045 & 8.152 & 15.803 & 21.502 & 27.618 & 37.754 & 51.249 & 68.212 & 100.258 & 148.987 \\
\hline 2. & $\begin{array}{l}\text { Pembiayaan yang } \\
\text { Diberikan (PYD) }\end{array}$ & 3.277 & 5.723 & 11.821 & 15.688 & 21.060 & 28.837 & 39.455 & 48.473 & 70.190 & 105.331 \\
\hline 3. & $\begin{array}{l}\text { Dana Pihak } \\
\text { Ketiga (DPK) }\end{array}$ & 2.918 & 5.910 & 12.129 & 15.933 & 21.193 & 28.730 & 37.828 & 53.522 & 77.640 & 117.510 \\
\hline
\end{tabular}

Sumber: Statistik Perbankan Syariah 2003-2011 
JIAI (Jurnal Ilmiah Akuntansi Indonesia)

Vol. 4, No. 2, Oktober 2019
ISSN (Print) : 2528-6501

ISSN (Online) : 2620-5432
Adapun data jumlah kelembagaan industri perbankan syariah selama dekade kedua dapat dilihat pada Tabel 4

di bawah ini:

Tabel 4 Jumlah Kelembagaan

Industri Perbankan Syariah pada Dekade Kedua (2002-2011)

\begin{tabular}{|c|c|c|c|c|c|c|c|c|c|c|c|}
\hline & \multirow{2}{*}{ Komponen } & \multicolumn{10}{|c|}{ Tahun } \\
\hline & & 2002 & 2003 & 2004 & 2005 & 2006 & 2007 & 2008 & 2009 & 2010 & 2011 \\
\hline 1. & $\begin{array}{l}\text { Bank Umum } \\
\text { Syariah (BUS) }\end{array}$ & 2 & 2 & 3 & 3 & 3 & 3 & 5 & 6 & 11 & 11 \\
\hline 2. & $\begin{array}{l}\text { Unit Usaha } \\
\text { Syariah (UUS) }\end{array}$ & 6 & 8 & 15 & 19 & 20 & 26 & 27 & 25 & 23 & 24 \\
\hline 3. & BPRS & 83 & 84 & 88 & 92 & 106 & 114 & 131 & 138 & 150 & 155 \\
\hline 4. & Jaringan Kantor & 229 & 337 & 443 & 550 & 693 & 802 & 1.069 & 1.258 & 1.763 & 2.101 \\
\hline
\end{tabular}

Sumber: Statistik Perbankan Syariah 2003-2011

2.3 Dekade Ketiga (Tahun 2012 -

\section{Saat Ini)}

Pada awal dekade ketiga ini, perbankan syariah Indonesia mengalami tantangan yang cukup berat dengan mulai dirasakannya dampak melambatnya pertumbuhan perekonomian dunia sebagai imbas dari krisis keuangan global di tahun 2008. Walaupun Indonesia termasuk negara yang masih mengalami pertumbuhan ekonomi yang stabil di dunia, namun pertumbuhan ekonomi Indonesia tidak setinggi yang diharapkan (BI, 2013).

\section{Fenomena}

perlambatan pertumbuhan tersebut dapat dilihat pada grafik perkembangan industri perbankan syariah sejak terjadinya krisis global di tahun 2008 hingga tahun 2014 tergambar pada Grafik 1 berikut:

\section{Grafik 1 Perkembangan Industri Perbankan Syariah Tahun 2008 - 2014}

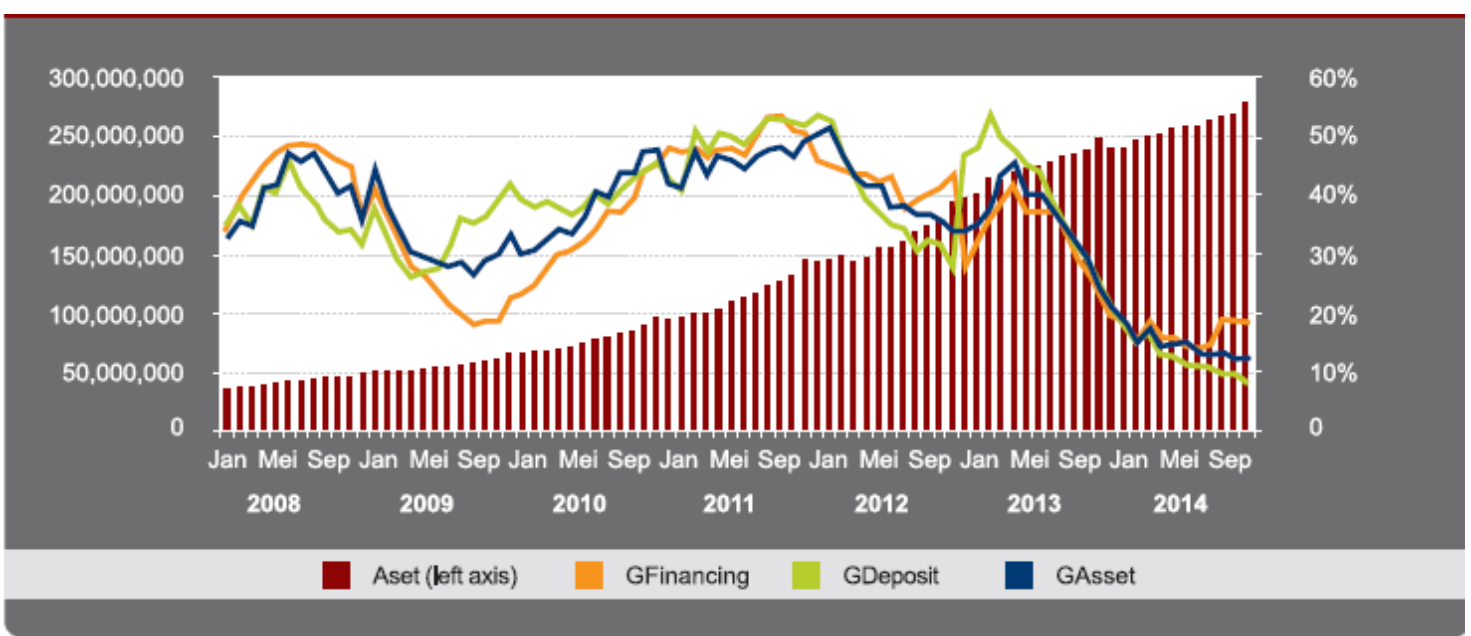

Sumber: Roadmap Perbankan Syariah 2015-2019 
Pada dekade ketiga ini, kondisi global, tren politik dan ekonomi global yang terus menerus berubah membuat sistem keuangan global sangatlah dinamis. Krisis keuangan global, perubahan iklim ekonomi global, kesenjangan pendapatan atau kondisi politik internasional secara langsung atau tidak langsung mempengaruhi sektor keuangan global yang pada akhirnya memberikan dampak pada sektor perbankan dan keuangan nasional. Oleh karenanya, industri perbankan syariah dituntut untuk memiliki daya tahan agar mampu menghadapi perubahan dan ketidakpastian (OJK, 2015).

Memasuki akhir tahun 2015, Masyarakat Ekonomi ASEAN (MEA) mulai diberlakukan. Dalam menghadapi MEA, Alamsyah (2012) mengemukakan beberapa kelemahan perbankan syariah nasional yang perlu mendapat perhatian. Pertama, belum tercapainya skala ekonomi bank syariah yang membuat operasional bank syariah di Indonesia kalah efisien, terlebih sebagian besar bank syariah masih dalam tahap ekspansi yang membutuhkan biaya cukup signifikan. Kedua, diferensiasi produk keuangan syariah di Indonesia yang dinilai masih kurang. Kendala ketiga adalah upaya untuk memenuhi gap SDI dari tenaga kerja domestik agar tidak diisi oleh tenaga kerja asing.

Pertumbuhan positif menandai perkembangan perbankan syariah tahun 2016 setelah 3 tahun terakhir mengalami perlambatan pertumbuhan. Perkembangan tersebut dapat dilihat dalam grafik 2 sebagai berikut:

\section{Grafik 2 Perkembangan Industri Perbankan Syariah Tahun 2012 - 2016}

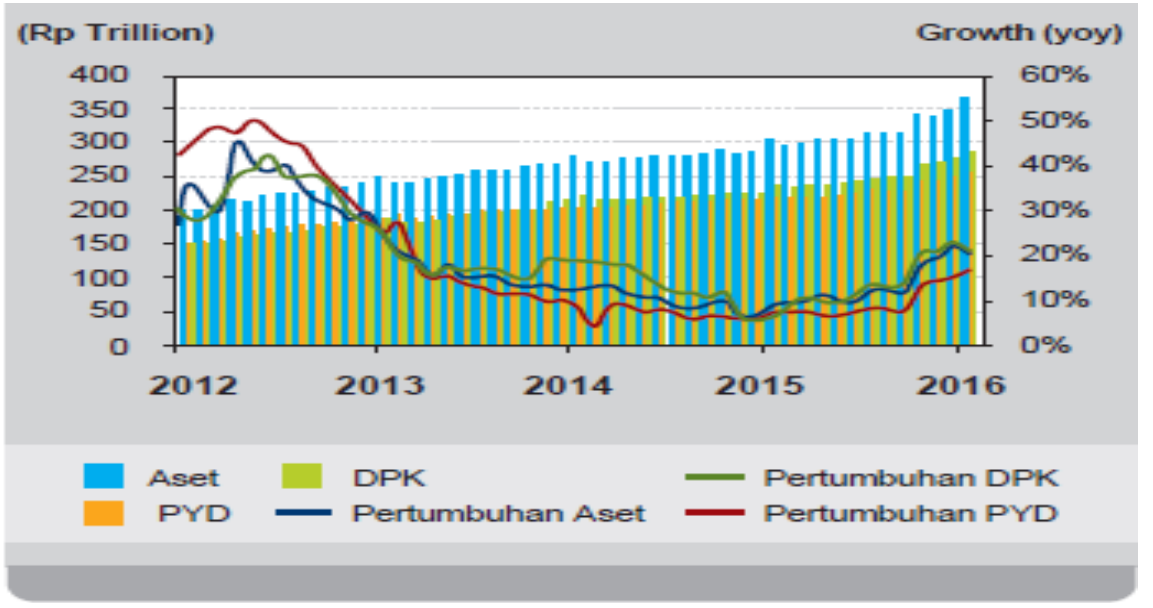

Sumber: Roadmap Keuangan Syariah 2017-2019 
Sebelum tahun 2016, komposisi aset perbankan syariah didominasi oleh dua BUS terbesar, yaitu BMI dan BSM. Secara teori, aset industri perbankan yang terkonsentrasi pada sedikit perusahaan saja dapat menimbulkan risiko konsentrasi (concentrated risk) sehingga apabila terjadi permasalahan pada sedikit perusahaan tersebut maka akan berdampak signifikan terhadap industri perbankan secara keseluruhan. Kehadiran Bank Aceh Syariah mengurangi dominasi dua bank syariah tersebut yang pada tahun 2015 mencapai $42,48 \%$ menjadi $36,84 \%$ pada Desember 2016 (OJK, 2017).

Pada dekade ketiga ini, beberapa Bank Umum Syariah telah melakukan Initial Public Offering (IPO) di Bursa Efek Indonesia (BEI), antara lain: Bank Panin Dubai Syariah (PNBS) pada tanggal 15 Januari 2014, BTPN Syariah pada tanggal 8 Mei 2018, dan disusul BRI Syariah pada tanggal 9 Mei 2018. BSM juga direncanakan akan melakukan IPO di tahun 2020.

Meskipun listing di BEI dapat berdampak positif bagi bank syariah, didalamnya terdapat sejumlah tantangan. Untuk itu, bank syariah harus menjaga kepercayaan investor dengan mempertahankan kinerja perusahaan serta dapat meyakinkan calon investor bahwa prospek industri bank syariah akan cerah kedepannya seiring dengan tren peningkatan sektor bisnis halal (Baderi, 2018).

Berikut adalah perkembangan kinerja keuangan industri perbankan syariah dalam dekade ketiga sebagaimana tercantum pada Tabel 5 di bawah ini:

Tabel 5 Perkembangan Aset, PYD dan DPK

Industri Perbankan Syariah pada Dekade Ketiga

(Dalam Triliun Rp),

\begin{tabular}{|c|c|c|c|c|c|c|c|c|c|c|c|}
\hline & \multirow{2}{*}{ Komponen } & \multicolumn{10}{|c|}{ Tahun } \\
\hline & & 2012 & 2013 & 2014 & 2015 & 2016 & 2017 & 2018 & 2019 & 2020 & 2021 \\
\hline 1. & Total Aset & 199,71 & 248,11 & 278,90 & 304,00 & 365,6 & 424,1 & 477,3 & - & & \\
\hline 2. & $\begin{array}{l}\text { Pembiayaan yang } \\
\text { Diberikan (PYD) }\end{array}$ & 151,06 & 188,55 & 204,31 & 218,72 & 254,7 & 293,5 & 329,3 & - & - & \\
\hline 3. & $\begin{array}{l}\text { Dana Pihak } \\
\text { Ketiga (DPK) }\end{array}$ & 150,44 & 187,19 & 221,89 & 236,02 & 285,2 & 341,9 & 379,9 & - & - & \\
\hline
\end{tabular}

Sumber: Statistik Perbankan Syariah 2012-2018 


\section{KESIMPULAN DAN SARAN}

\subsection{KESIMPULAN}

Penelitian ini bertujuan untuk mengkaji perkembangan industri perbankan syariah nasional dalam tiga dekade terakhir. Penelitian ini menggunakan metode studi literatur dengan meneliti artikel-artikel ilmiah, penelitian-penelitian, laporan resmi maupun pustaka lainnya yang mendukung topik dari penelitian ini. Hasil dari penelitian ini memperlihatkan bahwa selama tiga dekade terakhir, bank syariah di Indonesia mengalami berbagai kejadian-kejadian ekonomi yang mempengaruhi perkembangannya. Saat ini, berbagai kondisi perekonomian global banyak mempengaruhi industri perbankan syariah di Indonesia. Kondisi global, tren politik dan ekonomi global yang terus menerus berubah membuat sistem keuangan global sangatlah dinamis. Oleh karenanya, industri perbankan syariah dituntut untuk memiliki daya tahan agar mampu menghadapi perubahan dan ketidakpastian

\subsection{SARAN}

Beberapa saran yang dapat diberikan bagi penelitian selanjutnya adalah:

1. Penelitian ini kurang banyak menyajikan penelitian-penelitian terdahulu dan cenderung fokus pada kinerja keuangan perbankan syariah. Oleh karenanya dalam penelitian selanjutnya, dapat disajikan lebih banyak penelitian-penelitian terdahulu dengan topik yang beragam agar dapat menggambarkan perkembangan perbankan syariah dari berbagai faktor.

2. Penelitian selanjutnya dapat pula menyertakan kajian mengenai kondisi perkembangan industri perbankan syariah di berbagai negara, utamanya negara-negara dengan sistem keuangan syariah yang kuat sehingga dapat dijadikan referensi dalam mengembangkan sistem perbankan syariah di Indonesia. 


\section{DAFTAR PUSTAKA}

Alamsyah, Halim. 2012.

Perkembangan dan Prospek Perbankan Syariah Indonesia: Tantangan Dalam Menyongsong MEA 2015. Ceramah Ilmiah Ikatan Ahli Ekonomi Islam (IAEI), Milad ke-8 IAEI.

Ali, Zainuddin. 2008. Hukum Ekonomi Syariah. Jakarta: Sinar Grafika Offset.

Amin, Riawan. 2007. The Celestial Management (ZIKR, PIKR, MIKR). Jakarta: Senayan Abadi Publishing.

Antonio, Muhammad Syafi'i. 2007. Bank Syariah Dari Teori ke Praktik. Jakarta: Gema Insani

Ascarya. 2008. Akad dan Produk Bank Syariah. Jakarta: PT RajaGrafindo Persada

Azwar, Saifuddin. 2001. Metode Penelitian. Yogyakarta: Pustaka Pelajar.

Baderi, Firdaus. 2018. Menatap IPO Bank Syariah. Harian Ekonomi Necara 17 Januari 2018. http://www.neraca.co.id/article/957 99/menatap-ipo-bank-syariah [25 Juni 2019]

Bank Indonesia (BI). 2012. Outlook Perbankan Syariah 2013. Jakarta: Direktorat Perbankan Syariah Bank Indonesia.

Chodhury, Masudul Alam. 1986. Contributions To Islamic Economic Theory: A Study In Social Economics. New York : St. Martin's Press.

Hayat. 2014. Globalisasi Perbankan Syariah: Tinjauan Teoritis dan Praktis dalam Menghadapi Masyarakat Ekonomi ASEAN
2015. Jurnal UIN Malang. Vol. 11 (No. 2): Hal 293-314.

Mannan, Muhammad Abdul. 1992. Teori dan Praktek Ekonomi Islam. Yogyakarta : PT. Dana Bhakti Wakaf.

Miles, B.B., dan A.M. Huberman. 1992. Analisa Data Kualitatif. UI Press Jakarta.

Otoritas Jasa Keuangan (OJK). 2015. Roadmap Perbankan Syariah Indonesia 2015-2019. Jakarta: Otoritas Jasa Keuangan (OJK).

Otoritas Jasa Keuangan (OJK). 2017. Roadmap Pengembangan Keuangan Syariah Indonesia 2017-2019. Jakarta: Otoritas Jasa Keuangan (OJK).

Otoritas Jasa Keuangan (OJK). 2019. Statistik Perbankan Syariah Desember 2018. Jakarta: Otoritas Jasa Keuangan (OJK).

Otoritas Jasa Keuangan (OJK). 2019. Sejarah Perbankan Syariah. https://www.ojk.go.id/id/kanal/syar iah/tentang-syariah/Pages/SejarahPerbankan-Syariah.aspx [26 April 2019].

Permana, A.R dan Purba, A. 2008. Sekilas Ulasan UU Perbankan Syariah. Buletin Hukum Perbankan dan Kebanksentralan, Vol. 6 (No. 2).

Prastowo, Andi. 2010. Menguasai Teknik-teknik Koleksi Data Penelitian Kualitatif. Jogjakarta: DIVA Press.

Pusat Pengkajian dan Pengembangan Ekonomi Islam (P3EI). 2012. Ekonomi Islam. Jakarta: PT Raja Grafindo Persada. 
Raz, A.F; Indra, T.P.K; Artikasih, D.K; dan Citra, S. 2012. Krisis Keuangan Global dan Pertumbuhan Ekonomi: Analisa dari Perekonomian Asia Timur. Buletin Ekonomi Moneter dan Perbankan, Edisi Oktober 2012: 37 $-56$.

Riadi, Muchlisin. 2016. Pengertian, Tujuan, Prinsip dan Manfaat Ekonomi Syariah. https://www.kajianpustaka.com/20 16/09/pengertian-tujuan-prinsipdan-manfaat-ekonomi-syariah.html [27 April 2019].

Soemitra, Andri. 2009. Bank dan Lembaga Keuangan Syariah, Edisi Pertama. Jakarta: Kencana Prenada Media Grup.

Sudarsono, Heri. 2009. Dampak Krisis Keuangan Global terhadap Perbankan di Indonesia: Perbandingan antara Bank Konvensional dan Bank Syariah. La_Riba, Vol. 3, No. 1: 12-23

Sudarsono, Heri. 2012. Bank dan Lembaga Keuangan Syariah. Yogyakarta: Ekonosia.

Sudarsono, M.B. Hendri. 2002. Pengantar Ekonomi Mikro Islam. Yogyakarta: Ekonosia.

Sugiyono. 2011. Metode Penelitian Kuantitatif, Kualitatif dan $R \& D$. Bandung: Penerbit Alfabeta.

Surakhmad, Winarno. 1980. Metodologi Pengajaran Nasional. Bandung: Jemmars
Suroso, G.T. 2015. Masyarakat Ekonomi ASEAN dan Perekonomian Indonesia. https://bppk.kemenkeu.go.id/id/pub likasi/artikel/150-artikel-keuanganumum/20545-masyarakat-ekonomiasean-AEC-dan-perekonomianindonesia [20 Juni 2019]

Tarmidi, Lepi T. 1999. Krisis Moneter Indonesia: Sebab, Dampak, Peran IMF dan Saran. Buletin Ekonomi Moneter dan Perbankan, Maret 1999.

Undang-Undang (UU) Republik Indonesia Nomor 21 Tahun 2008 tentang Perbankan Syariah.

Universitas Muhammadiyah Jember. 2016. Rencana Induk Penelitian (RIP) Universitas Muhammadiyah Jember 2016 - 2020. Jember: LPPM Universitas Muhammadiyah Jember.

Widyarsa, M. R. 2012. Pendefinisian ASEAN Community di Era Globalisasi. Prosiding Seminar Nasional "Kontribusi Studi Hubungan Internasional dalam Integrasi ASEAN Community 2015". Konvensi Nasional AIHII, Malang, 8-10 Oktober.

Yusdani. 2005. Perbankan Syariah Berbasis Floating Market. Millah. Vol. IV, No.2 Januari 2005

www.bankaceh.co.id

www.bi.go.id

https://www.btpnsyariah.com

http://www.megasyariah.co.id

https://www.syariahmandiri.co.id 